\title{
AS PERSONAGENS INFANTIS LOBATIANAS FORMANDO UM BRASIL FUTURO
}

\author{
Elisângela da Silva Santos (PG-UNESP/Marília) ${ }^{1}$
}

\begin{abstract}
Resumo
Monteiro Lobato dissemina em seus personagens infantis a capacidade de reflexão do sujeito diante do aspecto social em que este vivencia, o autor se dedica aos livros infantis com o intuito de lançar o seu interesse na formação da criança. Diante disso, propõe em seus textos a necessidade de mudança da educação formal, acreditando na transformação do nosso sistema de ensino. Nesse sentido, aposta alto na fantasia, na imaginação, na irreverência, na ironia e no espírito crítico. O ideal do autor é de transformar os problemas sociais e econômicos em progresso. Por isso, propõe a construção de um país em que seus habitantes reflitam e ajam sobre seus principais obstáculos.
\end{abstract}

Palavras-chave: Formação da criança. Personagens infantis. Livros infantis.

\section{Introdução}

Monteiro Lobato começou a escrever para as crianças por acreditar que os iniciantes da leitura no Brasil não possuíam bons referenciais literários. A partir de 1921, demonstrou seu interesse pelo gênero infantil ao publicar o livro A Menina do Narizinho Arrebitado, a primeira versão do livro que iria integrar a série $O$ Sítio do Picapau Amarelo. Neste mesmo período, inaugura as editoras Monteiro Lobato \& Cia (1918) e a Companhia Editora Nacional (1925), onde foram publicados, além de obras de outros autores, as suas. Como editor atento, se preocupava tanto com o conteúdo existente nos livros quanto com a qualidade e com o formato de impressão deles.

O livro A Menina do Narizinho Arrebitado (1921) foi adotado nas escolas públicas de São Paulo como uma espécie de cartilha, sob o título de Narizinho Arrebitado. Washington Luís era o presidente da Província de São Paulo na época e se surpreende com a grande adesão ao livro por parte das crianças e, por isso, decide comprar muitos exemplares. Com tamanho incentivo, Lobato lança, neste mesmo ano de 1921, O Saci.

$\mathrm{O}$ autor começa a publicar suas obras infantis num contexto importante em que as

\footnotetext{
1 Aluna do programa de pós-graduação, doutorado, em Ciências Sociais, da Universidade Estadual Paulista "Júlio Mesquita Filho" - Faculdade de Filosofia e Ciências - UNESP/Marília, professora substituta na mesma Universidade e membro do grupo de pesquisa em Literatura e Cinema da Unesp. E-mail: licass20@yahoo.com.br
}

\begin{tabular}{|l|l|l|l|l|l|}
\hline Interface da Educ. & Paranaíba & v. 1 & n. 1 & p. 32-52 & 2010 \\
\hline
\end{tabular}


discussões sobre a questão da educação passam por grandes reformulações teóricas. Este contexto influenciará o autor na constituição de suas histórias. Conforme Marisa Lajolo (1985), no decorrer dos anos, os livros de Monteiro Lobato foram adquirindo um caráter de “escola informal". No livro Serões de Dona Benta (1937), este aspecto pode ser notado quando Pedrinho pede a avó que lhes ensine ciência, pois gostaria de saber mais sobre o assunto. Dona Benta sugere ao neto que leia muito, porém este afirma que os livros são difíceis de serem entendidos e que preferia ouvir a avó explicando oralmente para ele.

Portanto, o tema relativo à educação no livro proposto para análise é componente importante para compreendermos a proposta de Lobato referente à formação que a criança brasileira, representada nos seus livros por Pedrinho, Emília e Narizinho deveria receber. Para tanto, necessitamos ressaltar como a questão do ensino estava sendo colocada nos anos iniciais do século XX.

Como apontou Jorge Nagle (1985), a passagem do Brasil Monárquico para o Republicano não significou mudanças profundas no sistema de ensino e os primeiros anos dessa nova fase política foram fortemente influenciados pelo formato de ensino educacional que vigorava anteriormente. A agitação ideológica que pregava a democracia, a federação e a educação como aspectos indissociáveis para redenção do país foi passageira. Em pouco tempo, a educação não é mais priorizada, mas sim a composição do quadro político que iria governar o país. Apesar disto, duas reformas importantes do ensino foram feitas, a de Benjamin Constant (1890), de âmbito federal, e a de Caetano Campos (1882) de âmbito estadual.

É a partir da segunda década que se iniciam propriamente as discussões e pressões para um amplo desenvolvimento do sistema escolar. Movimentos políticos e sociais começam a sistematizar a questão do ensino. Antes disto, o ensino era tratado por homens públicos, intelectuais e ao mesmo tempo educadores, não havia, portanto uma discussão de especialistas sobre o tema, que só aparece no final da década de vinte. Sobre este aspecto, Nagle ressalta:

\footnotetext{
Uma das maneiras mais diretas de situar a questão consiste em afirmar que o mais manifesto resultado das transformações sociais [...] foi o aparecimento de inusitado entusiasmo pela escolarização e de marcante otimismo pedagógico: de um lado, existe a crença de que, pela multiplicação das instituições escolares, da disseminação da educação escolar, será possível incorporar grandes camadas da população na senda do progresso nacional, e colocar o Brasil no caminho das grandes nações do mundo; de outro lado, existe a crença de que determinadas formulações doutrinárias sobre a escolarização indicam o caminho para a verdadeira formação do homem brasileiro (escolanovismo). (NAGLE, 1974, p. 100).
}

Interface da Educ. v. 1

Paranaíba

\begin{tabular}{|l|l|l|l|} 
v. 1 & n. 1 & p. $32-52$ & 2010 \\
\hline
\end{tabular}

\begin{abstract}
n. 1
\end{abstract}

\begin{tabular}{|l|l|l|l|}
\hline v. 1 & n. 1 & p. $32-52$ & 2010 \\
\hline
\end{tabular}


A escolarização passa a ser encarada como "motor da história". A falta dela é responsável por todos os problemas que assolam o país, a confiança no processo de ensino leva seus entusiastas a acreditarem que é devido a sua falta que os problemas de ordem política, cultural, social e econômica se despontavam para a nação. $\mathrm{O}$ ensino era tido como princípio inquestionável para o "progresso" da sociedade brasileira.

A educação também aparecia como formadora de um caráter que o cidadão brasileiro deveria ter: o espírito nacional. O nacionalismo, naquele período, tornou-se um elemento valorativo importante na sociedade e, apesar do cunho idealista e sentimental, abriu espaço para o conhecimento aprofundado sobre o povo brasileiro.

Esse anseio demonstrado pela educação é resultado do processo de urbanização pelo qual o país passava. As novas teses pedagógicas originadas nos Estados Unidos e na Europa eram utilizadas para questionar as antigas metodologias de ensino, o que exigia uma densa reestruturação deste. Além disso, havia a crítica contra o analfabetismo que atingia a maioria da população:

[...] a ignorância reinante é a causa de todas as crises; a educação do povo é a base da organização social, portanto, o primeiro problema nacional; a difusão da instrução é a chave para a solução de todos os problemas sociais, econômicos, políticos e outros. (NAGLE, 1985, p. 263).

Havia, desse modo, uma falta de percepção sobre os profundos problemas da sociedade brasileira neste período, pois a educação seria a solução mais profícua. Essa superestimação do ensino o colocava como única possibilidade de ultrapassar a ordem oligárquica ainda presente, já que ela só encontrava sustentação por conta da "ignorância" popular, resultado da ausência de patriotismo e de cultura "prática" ou de formação técnica.

Os chamados entusiastas da educação naquele período tinham como fonte de inspiração teórica os ideais da Escola Nova. Para John Dewey, filósofo americano e um dos ideólogos desta vertente teórica, a escola deveria deixar de ser mero local de transmissão de conhecimento para assumir o papel de pequenas comunidades, e estas teriam o papel de integrar o indivíduo à sociedade e simultaneamente ampliar o acesso de todos a ela.

A implantação dos ideais da Escola Nova significou, conforme Nagle (1974), a implantação dos ideais de liberdade no setor. Um dos objetivos a ser conquistado era a "formação da personalidade integral do educando".

\begin{tabular}{|l|l|l|l|l|l|}
\hline Interface da Educ. & Paranaíba & v. 1 & n. 1 & p. 32-52 & 2010 \\
\hline
\end{tabular}


A escola primária sendo capaz de regenerar o homem brasileiro seria capaz também de regenerar a própria sociedade.

Anísio Teixeira (1900-1971) foi um dos adeptos ao pensamento da Escola Nova no Brasil. Para ele, nossa sociedade passava por mudanças e, por isso, era necessário que o ensino preparasse um novo homem, o homem moderno integrado à essa nova sociedade democrática:

Nos fins da década de 20 e 30, parecia, assim, que estávamos preparados para a reconstrução de nossas escolas. A consciência dos erros se fazia cada vez mais palpitante e o ambiente de preparação revolucionária era propício a reorganização. O país iniciou a jornada de $30 \mathrm{com}$ um verdadeiro programa de reforma educacional. (TEIXEIRA, 1976, p. 26).

A Escola Nova fazia uma crítica ao caráter livresco da "escola tradicional" presente até nas mudanças propostas. A medida que o ensino técnico-profissional foi se desenvolvendo, o ensino "livresco"e "abstrato" passava a sofrer críticas. Argumentavam que se o país estava realmente interessado em explorar sua inteligência, ela deveria ser aplicada e demonstrada na prática. A liberdade e a ciência eram tidas como valores de uma sociedade moderna, como o Brasil almejava ser, por isso a educação com um fim prático, racional e utilitário deveria ser priorizada. Este pensamento é explicado devido à vinculação com o ideais da filosofia pragmática norte-americana:

Essa nova escola, já agora para todos ou pelo menos, para muitos, não tinha por objetivo preparar o especialista das letras, das ciências e das artes, mas o homem comum, para o trabalho ou o ofício, tornando este, pelo desenvolvimento da civilização suficientemente técnico para exigir também treinamento escolar especial. (TEIXEIRA, 1976, p. 36).

Uma das preocupações dos ideólogos da educação naquele período era a falta de reestruturação do ensino técnico-profissional que, durante a Primeira República, não sofreu mudanças, conservando a base erigida desde o período imperial, que tinha como objetivo atender as camadas populares da sociedade, desta forma possuía mais que um plano de ensino, mas também um plano assistencial, sua intenção era a de regeneração pelo trabalho.

Na visão de Anísio Teixeira, para que a "escola técnica" fosse possível era necessária uma mudança em sua formulação, deveria se livrar da estrutura tradicional. De acordo com Barreira (2001), a elaboração teórica deste autor estava calcada na idéia de progresso. O progresso do conhecimento científico seria atingido pela propagação do método experimental. Como consequiência deste progresso, além da ciência, havia a necessidade do desenvolvimento também da tecnologia:

\begin{tabular}{|l|l|l|l|l|l|}
\hline Interface da Educ. & Paranaíba & v. 1 & n. 1 & p. 32-52 & 2010 \\
\hline
\end{tabular}


Com os olhos voltados para as sociedades desenvolvidas, sobretudo para que a educação escolar vinha nelas desempenhando, Anísio Teixeira analisará e interpretará a parte subdesenvolvida desse mundo moderno e proporá uma reforma educacional como estratégia de superação desse subdesenvolvimento. (BARREIRA, 2001, p. 103).

Devido às influências da filosofia pragmatista norte-americana, esse pensador da educação formulou propostas de métodos de ensino tais como as desenvolvidos nos Estados Unidos. A escola teria como fundamento formar o homem do mundo moderno. A sociedade brasileira deveria estar atenta para a consolidação de uma democracia verdadeira e também se ater às necessidades colocadas pelo mundo do trabalho industrial técnico e científico. Uma sociedade, portanto, que incentivasse as questões práticas e objetivas do mundo científico. Por isso, se fazia necessária uma reforma no sistema educacional, só assim a sociedade brasileira se constituiria de forma moderna e racional:

\begin{abstract}
Esse seria o quadro da educação escolar brasileira: os sistemas de ensino não estavam acompanhando as mudanças de base que a sociedade vinha experimentando, desde o início do século XX. Essa inadequação dos sistemas de ensino às reais necessidades da nova sociedade fez com que o ensino perdesse seu papel (histórico) de ser instrumento de controle social. Se, no passado, em perfeita harmonia com a organização social, os sistemas de ensino ofereciam uma educação de tipo vocacional, destinada a uma minoria (a classe dirigente), no presente, à semelhança do que ocorria em todas as sociedades modernas e desenvolvidas, a sociedade brasileira estaria a demandar uma educação para todos, uma educação voltada para a formação integral, e não apenas intelectual (BARREIRA, 2001, p. 114).
\end{abstract}

Notamos, portanto, que o ideário dos chamados "entusiastas da educação" no Brasil dos anos 20 e 30, compreendia o ensino almejado como forma prática de organizar o mundo do trabalho e torná-lo mais funcional às necessidades sociais, sendo que os indivíduos deveriam obter o conhecimento voltado para um fim prático e utilitário: o desenvolvimento de técnicas aplicáveis na prática, e, por conseguinte, o desapego pelo método "teórico", "abstrato" e "livresco".

É importante ressaltar que Monteiro Lobato muitas vezes compartilhou do pensamento de Anísio Teixeira. Há autores como Cassiano Nunes (2001) que acreditam que o objetivo didático dos livros infantis de Lobato foi inspirado pelo pedagogo. Essa hipótese é procedente se notarmos os ensinamentos passados às crianças por Dona Benta, cujo método se pautava pela oralidade e pelas experiências práticas que são realizadas no Sítio. Neste lugar não só se ensina a pensar na ciência como uma coisa prática, mas também como destiná-la a uma aplicação imediata.

\begin{tabular}{|l|c|c|c|c|c|}
\hline Interface da Educ. & Paranaíba & v. 1 & n. 1 & p. 32-52 & 2010 \\
\hline
\end{tabular}


Tanto que o espaço da imaginação é reservado para a descoberta do Poço de Petróleo e tantos outros engenhos. Portanto, Monteiro Lobato não escapava das questões que eram debate no seu tempo.

Desta forma, percebemos que o contexto histórico educacional que se insere o Sítio do Picapau Amarelo, passava por transformações e se atualizava de acordo com o objetivo da construção de um Brasil moderno.

\title{
1. Uma literatura de Formação
}

Monteiro Lobato tinha como um dos objetivos na sua literatura, a formação da criança, ou seja, a formação de uma mentalidade diferente, que considera a capacidade de reflexão do sujeito (independente de sua idade) sobre a realidade social que este vive. Como pontuou Zilberman (1998):

[...] a obra literária pode reproduzir o mundo do adulto: seja através da atuação de um narrador que bloqueia ou censura a ação de suas personagens infantis; seja através da veiculação de conceitos e padrões de comportamentos que estejam em consonância com os valores sociais prediletos; seja pela utilização de uma norma lingüística ainda não atingida por seu leitor, devido à falta de experiências mais complexa na manipulação com a linguagem. Assim sendo, os fatores estruturais de um texto de ficção [...] podem se converter no meio por intermédio do qual o adulto intervém na realidade imaginária, usando-a para incutir sua ideologia (ZILBERMAN, 1998, p. 11).

Dessa forma, a ideologia que Lobato tentou incutir nas crianças estava pautada na necessidade de mudanças, mesmo que fossem no plano imaginário, ideológico, criativo e crítico. Para ele, era necessário modificar a nossa realidade social e econômica, pois a julgava arcaica e ultrapassada.

No Sítio, os maiores agentes dessa transformação seriam as crianças, influenciadas pela avó Dona Benta, uma representante do universo adulto que passa aos netos valores e ensinamentos progressistas, despertando neles a vontade da ação. Como afirmou Lajolo:

\begin{abstract}
A obra infantil lobatiana é um projeto literário e pedagógico sob medida para o Brasil que viu nascer e multiplicar-se ao longo de mais de vinte anos. Monteiro Lobato aposta alto na fantasia, oferecendo a seus leitores modelos infantis - as personagens - cujas ações se pautam pela curiosidade, pela imaginação, pela independência, pelo espírito crítico, pelo humor (LAJOLO, 1985, p. 60).
\end{abstract}

É mediante estas características que "as crianças modelos" do sítio vão desenvolver projetos e planos extraordinários com o objetivo de modificar os problemas sociais e econômicos que o criador do Sítio/Brasil considerava mais inaceitáveis.

\begin{tabular}{|l|l|l|l|l|l|}
\hline Interface da Educ. & Paranaíba & v. 1 & n. 1 & p. 32-52 & 2010 \\
\hline
\end{tabular}




\section{Pedrinho: o formulador de projetos}

Entre as crianças, Pedrinho é a personagem que mais se destaca na formulação de planos, cujas idéias são as mais mirabolantes possíveis. Ele é no sítio um habitante esporádico, pois lá só passa o período de férias escolares. Esta personagem representa o pragmatismo lobatiano, as idéias mais ousadas partem da sua imaginação. Exemplo disso é a formulação de um projeto que visa à exploração de petróleo no sítio. Tal história se passa no livro O poço do Visconde (1936).

Ao ler os jornais, Pedrinho fica indignado com a nossa falta de exploração dos recursos naturais, por isso afirma:

\footnotetext{
- Bolas! Todos os dias os jornais falam em petróleo e nada de petróleo aparecer. Estou vendo que se nós aqui no sítio não resolvermos o problema o Brasil ficará toda a vida sem petróleo. Com um sábio da marca do Visconde para nos guiar, com as idéias da Emília e com a força bruta como a do Quindim, é bem provável que possamos abrir no pasto um formidável poço de petróleo. Por que não? (LOBATO, 1968, p. 2).
}

Pedrinho, portanto, chama toda a responsabilidade para os habitantes do sítio, se eles não resolvessem o problema, o Brasil conservaria sua posição inerte e sem encontrar petróleo. Todos possuem características importantes que podem auxiliar na abertura dos poços. É Pedrinho quem organiza o espaço onde as aulas do Visconde vão ser ministradas. O garoto ao comunicar ao sabugo de milho a sua idéia, fica sabendo que este se propõe a ser o professor de Geologia, já que sem saber algo da história da terra, não se pode pensar em petróleo. Pedrinho estava muito empolgado e foi avisar o pessoal que as aulas iriam começar naquele mesmo dia: "Foi assim que começou o petróleo no Brasil.” (LOBATO, 1968, p. 5).

Durante os serões de Visconde, as crianças demonstram um grande interesse e passo a passo, de forma detalhada, o sabugo de milho explica a elas a formação da terra. Pedrinho demonstra-se um aluno aplicado e esforçado em entender as explicações do mestre Visconde, respondendo corretamente todas as indagações deste.

As crianças, a cada explicação de Visconde, se sentem mais e mais interessadas e abismadas perante a nossa falta de exploração dos recursos naturais, principalmente após saberem da nossa capacidade geológica em produzir petróleo:

\footnotetext{
- Então porque não se perfura no Brasil?

- Porque as companhias estrangeiras que nos vendem petróleo não têm interesse nisso. E como não se tem interesse nisso foram convencendo o brasileiro de que aqui, neste enorme território, não faria petróleo. E os brasileiros bobamente se deixaram convencer? (LOBATO, 1968, p. 51).
}

Interface da Educ.
Paranaíba v. 1 n. 1 p. $32-52$ 
A crítica aqui é dirigida aos interesses dos trustes internacionais do petróleo, que impossibilita a entrada de novos países na concorrência, já que um dos objetivos é o controle do preço e o monopólio do produto por um grupo de países. O objetivo de Pedrinho era inserir o Sítio/Brasil nesta ordem, por isso, a todo o momento oferece um exemplo nítido da necessidade de abertura de poços:

Para mandar à cidade o seu café o Coronel Teodorico usa o carro de boi; cada carrada só leva 40 arrobas e gasta um dia inteiro para chegar lá e outro para voltar. Com um caminhão-automóvel ele levaria 200 arrobas em duas horas de viagem... (LOBATO, 1968, p. 68).

Pedrinho decide pelos outros habitantes que as aulas devem ser ministradas ao ar livre, pondo em prática os conhecimentos aprendidos. "É fazendo que o homem aprende, não é lendo, nem ouvindo discursos. Eu quero ciência aplicada..." (LOBATO, 1968, p. 72).

Nessa passagem, percebemos a crítica explícita do narrador social aos bacharéis, nossos intelectuais em sua maioria membros da elite agrária do país, que na concepção de Lobato eram homens sem ação (parasitas sociais), seus conhecimentos não eram aplicados na prática para solucionar os problemas sociais e econômicos que afetavam a maioria da população pobre brasileira, seus conhecimentos serviam apenas para serem exibidos nos discursos. Essa crítica de Monteiro Lobato pode ser notada principalmente em sua obra destinada ao público adulto, como por exemplo, no livro Mr. Slang e o Brasil (1959):

O parasitismo é maquiavélico e vence como camaleão, à custa de disfarçar-se e justificarse como sendo coisa útil. Temos, pois, antes de mais nada, de desmascará-lo, de pô-lo a nu, de provar que não passa de camouflage da utilidade (LOBATO, 1959, p. 77).

É esta situação que fez Lobato atribuir ao Brasil a alcunha de "pátria do bacharelismo". Os bacharéis ainda jovens preferiam, conforme Lobato, viverem afastados de atividades econômicas produtivas ao fazerem a opção por um emprego público que, na maioria das vezes, seria conquistado por meio de alguma indicação de pessoas influentes.

No Sítio, esse parasitismo não existe, todos os habitantes articulam o saber à ação, sempre buscando melhorar nossa situação de atraso com ações que façam o país progredir. Neste sentido, concordamos com Campos (1986), quando este afirma: "Obra engajada, a literatura infantil de Lobato nos apresenta a proposta 'desenvolvimentista' deste autor para o Brasil: o progresso é categoria central que percorre toda a obra [...]" (CAMPOS, 1986).

\begin{tabular}{|l|l|l|l|l|l|}
\hline Interface da Educ. & Paranaíba & v. 1 & n. 1 & p. 32-52 & 2010 \\
\hline
\end{tabular}


Pedrinho é a personagem mais empreendedora do Sítio. É ele quem decide e põe em prática o mais rápido possível o aprendizado de Visconde, oferecendo as diretrizes para Emília e Narizinho:

Pedrinho deu a ordem à boneca para que cuidasse da lenha. Emília aplicou o faz-de-conta, e num momento dez carros de boi começaram um vaivém contínuo do capoeirão até ali. [...]. Narizinho, se encarregue das casas (dos operários) e do barracão para as máquinas. A Menina também aplicou o faz-de-conta, de modo que num instante surgiu da terra um excelente barracão de madeira, com telhado de zinco, para as máquinas; e a cem metros dali uma série de casas para operários, muito bonitas e higiênicas, tão bonitas que Pedrinho achou demais (LOBATO, 1968, p. 100).

Pedrinho era o superintendente do campo, por isso também foi construído um escritório para ele, de lá fez os pedidos das máquinas necessárias nos Estados Unidos, já que no Brasil elas ainda não existem. A cada dificuldade encontrada, o menino recorria aos saberes de Visconde, este aconselhava enquanto aquele agia e tomava as decisões.

Assim, as crianças preparavam tudo para iniciar a perfuração dos poços quando certo dia, enquanto estavam reunidos na sala de jantar para a refeição, Dona Benta pergunta aos netos o que eles fariam com o dinheiro que iriam lucrar com o petróleo e Pedrinho, como bom empresário capitalista, diz que queria viajar para conhecer o mundo: “- Por que, vovó, como posso saber de que modo empregar meus capitais, se nada conheço do mundo? Tenho de, primeiramente, estudar o mundo para verifica o que o mundo mais precisa, não acha?” (LOBATO, 1968, p. 100).

Todos os habitantes fazem propostas práticas e concretas que visem o bom funcionamento da sociedade capitalista, tendo como modelo sempre os Estados Unidos. No Brasil, por exemplo, a necessidade vista como imprescindível era a perfuração dos poços de petróleo e quando este processo inicia, o sítio se transforma e ganha ares de uma cidade urbana. As personagens que mais notam estas mudanças são Tia Nastácia e Dona Benta:

\begin{abstract}
- Nossa Senhora! - exclamou tia Nastácia ao ver a torre de perto. - Quanto ferro! Neste andar Seu Pedrinho muda o "semblante" do Sítio, Sinhá. A coisa já está ficando que a gente não conhece mais nada. Virando uma cidadinha estrangeira, com essas casas de operários e o "bangalão" do Mister. E as caras? Tudo esquisito. Aquele ali, vermelho como um presunto aquele lá, de cabelo igualzinho cabelo de milho novo. Credo!... (LOBATO, 1968, p. 121).
\end{abstract}

Esse processo de modernização partiu das crianças, a geração mais nova do sítio, entretanto, mesmo iniciado este processo, existem relações nesta pequena sociedade que irão permanecer, como por exemplo, o mandonismo exercido por Dona Benta, e a relação travada entre os habitantes e a "negra de estimação" que enxerga, mas não tem acesso às benesses do "novo"

\begin{tabular}{|l|l|l|l|l|l|}
\hline Interface da Educ. & Paranaíba & v. 1 & n. 1 & p. 32-52 & 2010 \\
\hline
\end{tabular}


sistema que se institucionaliza a partir deste momento no Brasil ideal, construído pelas crianças. Conforme os autores de Furacão na Botocúndia (1997):

Militante da causa do progresso, Monteiro Lobato percebeu acertadamente que só através dos jovens seria possível apressar a modificação do mundo. Assim, deduzindo que, ao influir na formação da criança, contribuiria para construir o Brasil do futuro, ele resolve dedicar-se definitivamente aos livros infantis. (AZEVEDO, CAMARGOS, SACCHETTA, 1997, p. 311).

É insistindo nesta formação da criança que Lobato dá continuidade aos aprendizados científicos no livro Serões de Dona Benta (1937). E novamente neste livro, é Pedrinho quem sugere à avó que ela ministre serões científicos, pois nos livros ele não encontrava facilidade e nem clareza para entender o assunto: “- Sinto uma comichão no cérebro, disse Pedrinho. Quero saber coisas. Quero saber tudo quanto há no mundo..." (LOBATO, 1966, p. 08).

Nas aulas, as crianças ouvem os ensinamentos de Dona Benta e cada vez mais ficam interessadas em saber, mas sempre Pedrinho demonstra uma atitude de liderança e seus pedidos e observações são sempre considerados pela avó. Percebemos que por meio destas aulas, Lobato sugere a superação da leitura de mundo do Brasil inculto, por meio de explicações científicas pautadas na oralidade e sempre com a mediação da velha avó. Isso pode ser notado pela seguinte intervenção de Pedrinho:

Anda mamãe muito iludida, pensando que aprendo muita coisa na escola. Puro engano. Tudo quanto sei me foi ensinado por vovó, durante as férias que passo aqui. Só vovó sabe ensinar. Não caceteia, não diz coisas que não entendo. Apesar disso, tenho que passar oito meses na escola. Aqui só passo quatro... (LOBATO, 1966, p. 219).

A crítica embutida nesta passagem diz respeito à educação formal, que demonstra ser arcaica e pouco científica. No momento que Lobato escreve para as crianças ele dialoga questões como estas com pedagogos que pensavam como ele, numa transformação no nosso sistema de ensino. Estes pedagogos, Anísio Teixeira, Carneiro Leão e Fernando Azevedo, escreveram na década de trinta o Manifesto da Educação que, dentre outros aspectos, pregava um ensino prático como forma de organização do mundo do trabalho, tornando-o mais funcional às necessidades sociais. O indivíduo, portanto deveria se voltar para um fim prático e utilitário, dispensando o caráter teórico, abstrato e livresco do ensino vigente.

Estas críticas dirigidas à instituição escola conforme Lajolo (1985), não compromete, mas reforçam o valor formativo da obra infantil de Lobato, pois em seus livros a questão central esta na irreverência, na ironia, na leitura crítica e no questionamento.

\begin{tabular}{|l|l|l|l|l|l|}
\hline Interface da Educ. & Paranaíba & v. 1 & n. 1 & p. 32-52 & 2010 \\
\hline
\end{tabular}


No livro Histórias de Tia Nastácia (1937), Pedrinho quando lia os jornais - assim como a idéia da exploração do poço de petróleo no sítio - pergunta à Dona Benta o significado da palavra folclore, e ela responde:

[...] folk quer dizer gente, povo e lore quer dizer sabedoria, ciência. Folclore são as coisas que o povo sabe por boca, de um contar para o outro, de pais a filhos - os contos, as histórias, as anedotas, as superstições, as bobagens, a sabedoria popular etc, e tal. (LOBATO, 1960, p. 07).

Então Pedrinho sugere que Tia Nastácia, como sendo parte do povo, conte suas histórias para os habitantes do sítio, assim todos conheceriam um pouco do seu imaginário.

Durante as primeiras histórias, Pedrinho defende Tia Nastácia das críticas ferrenhas feitas pelos outros habitantes, diz que é importante conhecer a mentalidade do nosso povo. Mas no decorrer do livro sua posição muda e também passa a atacar com ofensas deterministas a criada, o que pode ser observado na seguinte sentença: "Bem se vê que é história contada por negras velhas, cozinheiras. Só faltou transformarem a moça num saquinho de sal, a espingarda em uma cabeça de alho e os cavalos num frango assado.” (LOBATO, 1960, p. 47).

Ou então na passagem seguinte, quando Tia Nastácia conta uma versão da história de João e Maria, na qual há a presença de um "negro mentiroso" que quer se dar bem no final da história, casando-se com a princesa que João conseguira conquistar. Porém, o negro não consegue realizar tal proeza. Por isso Pedrinho diz: “-O tal negro entrou aí - disse Pedrinho - porque no Brasil as histórias são contadas pelas negras, que gostam de enxertar personagens pretos como elas." (LOBATO, 1968, p. 47).

Essa observação de Pedrinho nos faz concluir que no Brasil de Lobato, os negros só podem ser mencionados por outros negros, diferentes culturas não podem dividir o mesmo espaço, mesmo que seja no imaginário e por isso Tia Nastácia é questionada, já que ao narrar relatos para a parcela ilustre do sítio, "enxerta" uma personagem negra que na sociedade já tem espaço negado e no nível da imaginação este espaço também não existe. Nota-se que o negro só pode conseguir algo mentindo, ou seja, por mais empreendedor, crítico e progressista que Pedrinho possa ser, ele conserva características fundamentadas e herdadas da ordem escravocrata, na qual o espaço do negro no país se resumia à cozinha e à senzala.

\begin{tabular}{|l|l|l|l|l|l|}
\hline Interface da Educ. & Paranaíba & v. 1 & n. 1 & p. 32-52 & 2010 \\
\hline
\end{tabular}




\section{Emília: do desrespeito à perversidade}

A boneca Emília começa a falar e a ganhar características humanas numa história narrada no livro Reinações de Narizinho (1932). Narizinho a leva ao consultório do doutor Caramujo e este dá à ela uma pílula falante e, no momento que a engole, a boneca começa a falar e fala uma hora sem parar. Narizinho fica preocupada com a boneca e diz ao médico que era melhor que ela engolisse um pílula mais fraca, porém o doutor diz que Emília falaria até cansar, pois ela tinha a "fala recolhida" que tinha que ser exposta.

Quando chegaram no Sítio, Dona Benta pela primeira vez ouviu a boneca falar: "Tamanho susto levou Dona Benta, que por um triz não caiu de sua cadeirinha de pernas serradas. De olho arregaladíssimo, gritou para a cozinha... - Corra, Nastácia! Venha ver este fenômeno..." (LOBATO, 1959, p. 35).

Tia Nastácia não acreditou em Dona Benta quando ela disse que a boneca estava falando e disse que Narizinho estava "mangando" dela, mas neste momento Emília afirma:

\footnotetext{
- Mangando o seu nariz! - gritou Emília furiosa. Falo, sim e hei de falar. Eu não falava porque era muda, mas o doutor Cara-de-coruja me deu uma bolinha de barriga de sapo e eu enguli e fiquei falando e hei de falar a vida inteira, sabe?

- A negra abriu a maior boca do mundo.

- E fala mesmo, Sinhá!... exclamou no auge do assombro. Fala que nem gente! Credo! O mundo está perdido...

E encostou-se à parede para não cair. (LOBATO, 1959, p. 36).
}

Percebemos que Emília inicia sua participação no mundo humano de forma petulante e irreverente, ela responde de modo impulsivo e repentino e a primeira frase que dirige à Tia Nastácia demonstra um desrespeito, que transgride a forma como uma criança se dirigia aos mais velhos. Ela grita eufórica: "mangando o seu nariz!”, ou seja, ela já nasce com as características que vão marcar toda sua atuação no Sítio do Picapau Amarelo: a irreverência, a espontaneidade, a crítica, o desrespeito e até o modo perverso de tirar conclusões.

No livro Serões de Dona Benta (1937), a ex-boneca responde às indagações que Dona Benta faz durante as aulas, como por exemplo, quando a velha senhora pergunta numa lição sobre o ar, o que significava este fenômeno, e a boneca: "É essa coisa branca que a gente respira" ou então na lição sobre a água, Dona Benta indaga novamente que é água, e Emília responde: "Uma coisa que a gente bebe".

Suas falas demonstram sempre um espírito prático e simples de falar. Não possuem uma característica rebuscada e erudita. Conforme o próprio Lobato, "Emília é infernal", uma

\begin{tabular}{|l|c|c|c|c|c|}
\hline Interface da Educ. & Paranaíba & v. 1 & n. 1 & p. 32-52 & 2010 \\
\hline
\end{tabular}


personagem que foge do seu controle e fala o que quer.

Emília foi confeccionada por Tia Nastácia, a pedido de Narizinho, tem os "olhos de retrós preto e sobrancelha tão lá em cima que é ver uma bruxa” (LOBATO, 1959, p. 12), porém Narizinho gosta muito dela e a trata como se fosse gente. Entretanto, quando Emília começa a falar, ela não respeita ninguém e é a sua "criadora", a criada da casa, a vítima das mais perversas falas da boneca. É interessante ressaltar que a boneca deve ser "remendada" o tempo todo por Tia Nastácia, assim como o sabugo de milho Visconde, o que sugere que a criada não tem acesso a bons materiais para construir algo duradouro, seu universo material que se resume a uma espiga de milho e retalhos de panos para a construção de bonecos desajeitados.

No sítio, Emília é tratada por Dona Benta como uma igual, ou seja, a avó oferece o mesmo tratamento à ela e aos seus netos. Esta situação oferece margem à boneca uma liberdade de fazer o que ela tem vontade e o que entende como correto. Entretanto, ela não deixa de ser submetida à autoridade da matriarca, como pode ser comprovado na seguinte afirmação de Narizinho no livro Serões de Dona Benta (1937): “A sua presença, por exemplo, vovó faz que as criaturas se comportem de outra maneira - sobretudo a Emília. Assim que a senhora sai, ela vira outra [...]" (LOBATO, 1966, p. 23).

Já Tia Nastácia não conjuga da mesma respeitabilidade afetiva que a boneca concede à Dona Benta. Isto pode ser observado com mais clareza no livro Histórias de Tia Nastácia (1937). Nele a boneca faz as críticas mais ferrenhas à criada, devido a "ingenuidade" e "simplicidade" de seus relatos. Ela se sente no direito de julgá-los e atribuir conceitos avaliativos no final de cada história. Observemos o que ela diz no final da história intitulada "Pássaro Preto":

Tudo bobagens de negra velha. Nesta história vejo uma fieira de negras velhas, cada qual mais boba que a outra - que vão passando para diante, cada vez mais atrapalhada. [...]. O que vale é que você mesma confessa não ter culpa das idiotices da história, senão eu cortava um pedaço desse beiço...

- Emília respeite os mais velhos! - ralhou Dona Benta.

- A senhora perdoe - disse a pestinha; mas, cá para mim, isto de respeito nada tem com a idade. Eu respeito uma abelha de um mês de idade que me diga coisinhas sensatas - mas se Matusalém vier para cima de mim com bobagens, pensa que boto fogo na barba dele? Ora, se boto!... (LOBATO, 1960, p. 36).

\section{Conforme Campos (1986):}

Emília exerce seu poder através da ação. O poder de Emília é originário de suas idéias, de sua ousadia, e de seu empreendimento e ação. Ela é a própria imagem do indivíduo empreendedor, apto e esperto, que para Lobato identifica aqueles que são capazes de vencer na competição pela vida (CAMPOS, 1986, p. 141).

\footnotetext{
Interface da Educ.
} Paranaíba V. 1 n. 1 p. $32-52$ 2010 
No livro O poço do Visconde (1936), é Emília que se encarregada parte financeira para as máquinas e equipamentos necessários para a perfuração dos poços de petróleo. É através do fazde-conta que ela consegue fazer com que as técnicas precisas "chovam" de repente no sítio, o que pode ser observado no seguinte diálogo entre ela e Pedrinho:

\footnotetext{
- Olhe, Emilinha, encarregue-se você desta parte financeira. Dê um jeito de o dinheiro ser entregue hoje mesmo à firma para fazer a remessa.

- Banco? Não me fio em bancos, Pedrinho. Vou fazer o dinheiro chuviscar em cima da cabeça de Mister McGowen. Quer ver? E voltando-se para o céu, gritou:

- Nuvenzinhas, nuvenzonas, que cochilando passais pelo azul! Correi até à casa de Míster... Mc o quê, Pedrinho?

- McGowen - gritou o menino do fundo do escritório.

-...de Mister McGowen e despejai-lhe na cabeça uma chuva de 105.742 pingos doláricos por conta da Companhia Donabentense de petróleo. (LOBATO, 1968, p. 105).
}

Os dólares são despejados na cabeça de Mister McGowen e os trabalhos dão início no sítio. Dona Benta, ao perguntar à Emília o que ela faria com o dinheiro lucrado com a abertura dos poços, ouve a seguinte resposta:

- Minha idéia é esta. A verdadeira vocação dos homens é escravizarem-se ao dinheiro. Assim que uma pessoa sacode no ar um pacote de notas, gritando: 'Quem quer? Quem quer?'imediatamente aparecem mil mãos estendidas, dizendo: - 'Eu quero! Eu quero!'E o dono das notas distribui o dinheiro, mas prende aquelas com algemas de aço - os juros (LOBATO, 1968, p. 108).

Percebemos que o pensamento da boneca está extremamente fundamentado nas relações de empréstimos a juros, em que o detentor do dinheiro tem plenos poderes sobre aqueles que não o tem, por isso, podem definir os valores dos juros a serem pagos. Emília seria, portanto, uma espécie de agiota do Sítio, ou seja, realizaria as transformações financeiras ou comerciais tendo como objetivo a obtenção de lucros exagerados.

A boneca Emília, portanto, é a personagem que Lobato demonstrou sua maior aposta na fantasia e na utopia, ela, por ser uma boneca e não humana como as outras crianças, Narizinho e Pedrinho, não deve satisfação a ninguém, pois não está presa às regras de conduta, o narrador atribui a ela o pensamento mais absurdo e despojado que tinha a intenção de dizer e se expressa através dela.

\section{Visconde e a ciência aplicada}

Visconde é um sabugo de milho que assim como Emília foi costurado por Tia Nastácia, seu figurino é composto pela cartola, bengala e fraque, condensando uma ostentação da forma de

\begin{tabular}{|l|l|l|l|l|l|}
\hline Interface da Educ. & Paranaíba & v. 1 & n. 1 & p. 32-52 & 2010 \\
\hline
\end{tabular}


vestir das elites brasileiras tradicionais. Seu nome, visconde é um título nobiliárquico superior ao de barão e inferior ao de conde, ou seja, representa também um elemento do Brasil tradicional. Esta figura, portanto, marca uma situação de ambigüidade, pois ao mesmo tempo em que Visconde acredita na ciência como algo universal, ela traz consigo aquilo que Lobato criticava no país: a aparente representação intelectual das elites agrárias, devido a sua vestimenta.

Sobre sua roupa, poderíamos sugerir que tem estes elementos tradicionais porque foi confeccionada por Tia Nastácia, sua referencia sobre alta cultura era a vestimenta dos barões e viscondes que habitavam o Brasil. cultura, porém mandavam seus filhos para estudarem na Europa, ou seja, o país moderno é fundamentado no trabalho braçal da população negra e essa característica produziria sempre uma marca de nascença aos seus brinquedos. Assim, poderíamos sugerir que Tia Nastácia utiliza como referencial para a construção de seus bonecos, como o Visconde, por exemplo, a cultura de elite que ela estava acostumada a servir.

Gilberto Freyre, em Casa-Grande\& Senzala (2001), afirmou que no Brasil as bonecas que mais se produziam eram as de pano, assim como Emília. Para este autor, esta talvez tivesse sido uma influencia africana.

No livro O poço do Visconde (1936), Visconde é chamado pelo narrador de "fidalgo mais pobre do mundo" (LOBATO, 1968, p. 70), apesar de ser um visconde, nunca viu na sua frente, ou teve posse de um "tostão furado". Aqui poderíamos sugerir a falência do modo de vida das elites agrárias que Lobato criticava tendo como um dos motivos, a falta de empreendimento em outros negócios que não se resuma à produção de café. Visconde, assim como os outros habitantes do sítio só conseguirá obter lucro através da perfuração dos poços de petróleo. Por isso, o sabugo será um fervoroso defensor da extração de petróleo no país:

\footnotetext{
- Realmente. No dia em que tal acontecer e o Brasil passar de comprador a vendedor de petróleo, então deixaremos de ver essa coisa tristíssima de hoje - milhões de brasileiros descalços, analfabetos, andrajosos - na miséria. O Brasil tem todos os elementos para tornar-se um país riquíssimo - mas riquíssimo de verdade, e não, com hoje, apenas rico de "possibilidades" - ou de "garganta".

- Bravos, Visconde! - exclamou Dona Benta - nem parece que é um sabuguinho que está falando.

- Pudera! - gritou Emília. - Num país onde até os ministros não pensam em petróleo, ou quando falam nele é para negar, só mesmo dando a palavra a um sabugo. Viva o senhor Visconde do Poço Fundo! (LOBATO, 1968, p. 62).
}

Visconde foi o articulador intelectual dos poços de petróleo abertos nas terras de Dona Benta.

\begin{tabular}{|l|l|l|l|l|l|}
\hline Interface da Educ. & Paranaíba & v. 1 & n. 1 & p. 32-52 & 2010 \\
\hline
\end{tabular}


Ele representa a ciência aplicada, que visa a melhoria da vida do homem na terra. $\mathrm{O}$ ensinamento que ele fornece às crianças é técnico, por isso demonstra a visão do narrador social, Lobato com uma visão pragmática que possuía, defendia um ensino que se pautasse pela técnica avançada, com soluções imediatas. Neste sentido, acentua Campos (1986):

O personagem Visconde de Sabugosa, por sua vez, tem o poder da ciência e da técnica.

É um intelectual e, como Dona Benta, um sábio. Mas é um tipo de sábio diferente. Sua ciência é positiva e pragmática, tem objetivos concretos, como, por exemplo, aumentar a riqueza material desfrutável no mundo. Lobato aproveitou a figura do Visconde para criticar os "sábios" oficiais, os membros dos Institutos Históricos e das Academias de Letras (CAMPOS, 1986, p. 142).

A finalidade de Visconde no Sítio é auxiliar as crianças na construção de um país mais desenvolvido economicamente e socialmente, é ele quem fornece as diretrizes científicas que devem ser tomadas. O químico-geólogo, Mr. Champignon, trazido pela companhia de perfuração de poços nos Estados Unidos, ao dizer à Dona Benta sua opinião sobre os conhecimentos de Visconde, afirma:

\begin{abstract}
Acho que o senhor Visconde de Sabugosa do Poço Fundo [...], é na realidade um grande sábio. E isso me assombra, extraordinariamente, porque, afinal de contas, não passa de um sabugo. Logo que aqui cheguei meu queixo caiu; primeiro, ao ver um sabugo vivente; depois, ao verificar que era falante; e por fim, ao reconhecer nele um sábio mas sábio de verdade, desses que descobrimos coisas e mudam as diretrizes da civilização (LOBATO, 1968, p. 133).
\end{abstract}

Visconde, portanto, tem sua sabedoria legitimada por um técnico norte-americano - que também estava trabalhando na Companhia de petróleo de Dona Benta - Mr. Champignon, que havia encaminhado uma carta à Sociedade Científica da América sobre o sabugo, apesar de estar convencido de que todos duvidariam deste fenômeno, ele acredita que Visconde ainda haveria de assombrar o mundo.

Com o dinheiro lucrado do petróleo extraído dos poços da Companhia Donabentense, os habitantes fazem sugestões de como reverter este lucro para o resto da população, a de Visconde foi:

\footnotetext{
- Eu acho que devemos criar casas de ciência para o aproveitamento dos meninos que mostrarem vocação para os altos estudos. E mais tarde poderemos criar uma universidade como a de Harvard.

- Aprovado! -Senhor Visconde. Fica desde já nossos planos a criação da Universidade Sabugosa, da qual o nosso viscondinho será o primeiro reitor e o professor de Geologia disse Dona Benta. (LOBATO, 1968, p. 215).
}

Interface da Educ.

Paranaíba

v. 1

n. 1

p. $32-52$

2010 
Percebemos, portanto, que Visconde representa a autoridade da ciência no Sítio do Picapau Amarelo. Dono de um discurso competente, ele consegue solucionar os principais problemas que os "homens de verdade" não ofereciam solução, sua precisão e ensinamentos bem colocados em suas aulas de geologia, ofereceram os saberes mais imprescindíveis para que as crianças do Sítio/Brasil conseguissem mudar nossa situação de atraso e pobreza que assolava em sua maioria a população rural.

\section{Narizinho: a representante da responsabilidade social}

É relatando a história da menina de nariz arrebitado que Lobato se envereda para o gênero literário infantil. Narizinho é a encantadora neta de dona Benta, que vive com ela no sítio. Nos livros, seus pais nunca são citados, desde que nascera fora criada pela avó com o auxílio de Tia Nastácia. Nas palavras do narrador:

Dona Benta é a mais feliz das vovós, porque vive em companhia da mais encantadora das netas - Lúcia, a menina do narizinho arrebitado, ou Narizinho como todos dizem. Narizinho tem sete anos, é morena cor de jambo, gosta muito de pipoca e já sabe fazer uns bolinhos de polvilho bem gostosos. (LOBATO, 1959, p. 11).

Dona Benta, portanto é a única responsável, mencionada no livro, pela neta. Sua companheira inseparável é a boneca Emília. A menina representa em muitas passagens a bondade e o respeito que sua boneca muitas vezes não possui. Ao contrário de Emília, as colocações de Narizinho são resultantes de uma reflexão, o que muitas vezes faz com que sua vivacidade e seu espontaneismo sejam apagados. Narizinho, em muitas passagens, demonstra a influência que ela recebeu de sua avó, de acordo com Campos (1986):

[...] Lobato jamais colocou as figuras do pai e da mãe nas suas histórias infantis. Ao suprimi-los, Lobato suprimiu também uma outra representação - a repressão. Isso porque, se o pai e a mãe são símbolos do amor, eles são também os símbolos da autoridade tolerante, culta e persuasiva. Não é o pai quem manda, é a avó velha e sábia que persuade; embora Dona Benta use sua autoridade com segurança e firmeza. (LOBATO, 1986, p. 136).

A figura da velha avó simpática, compreensiva e que aceita as idéias, planos e situações criados pelos netos e pela boneca, ameniza uma autoridade máxima e repressiva que poderia ser desempenhada pelos pais das crianças, como apontou este autor.

Narizinho, no entanto, não escapa de determinados valores passados por Dona Benta. Em uma passagem no livro Reinações de Narizinho (1932), Pedrinho chega a afirmar que "apesar" da

\begin{tabular}{|l|l|l|l|l|l|}
\hline Interface da Educ. & Paranaíba & v. 1 & n. 1 & p. 32-52 & 2010 \\
\hline
\end{tabular}


prima viver na roça, era muito mais inteligente e esperta que as meninas que moravam na cidade. Neste caso, podemos inferir que esta esperteza fora adquirida através da vivencia dela com Dona Benta e devido os ensinamentos desta.

A menina possui uma ética e um refinamento na expressão de sua fala, o que pode ser observado numa passagem do livro O poço do Visconde (1936) onde Dona Benta ao repreender Emília sobre sua foram de falar, ouve a seguinte resposta da boneca:

\begin{abstract}
- Dona Benta, a senhora me perdoe, mas quem torto nasce, tarde ou nunca se endireita. Nasci torta. Sou uma besteirinha da natureza - ou dessa negra beiçuda que me fez. E, portanto, ou falo como quero ou calo-me. Isso de falar como as professoras mandam, que fique para Narizinho. Pão para mim é pão; besteira é besteira - nem que venha da Inglaterra ou dos Estados Unidos. Cá comigo é ali na batata (LOBATO, 1968, p. 63).
\end{abstract}

Narizinho é uma "menina real" que, conforme Emília, deve obedecer determinadas regras de conduta, já a boneca não tem compromisso com os seres humanos, não passa de um acidente da natureza, que age como humano, porém não tem necessidade de ter uma ética, de agir de acordo com as condutas humanas, consideradas corretas.

Neste mesmo livro, O poço do Visconde (1936), Pedrinho pergunta à Narizinho como fariam para iniciar a abertura dos poços se não tinham dinheiro, e ela responde: “- Isso é lá com você que é homem - respondeu a menina. - Dinheiro é assunto masculino - arrume-se (p. 71).

O menino recorre à Emília e só ela consegue através do "faz-de-conta" arranjar o dinheiro necessário. Ou seja, apenas a boneca consegue agir, enquanto Narizinho delega responsabilidade ao primo, abdicando-se da funcionalidade atribuída a ela, já que o dinheiro, na sua concepção é um assunto que deve ser resolvido por um homem.

Narizinho é nomeada a Diretora Comercial da Companhia de petróleo Donabentense, por isso Dona Benta questiona o que fariam com o dinheiro gerado com o lucro da venda do líquido, que já havia atingido a marca de 17 milhões de cruzeiros. A menina, a princípio sugere: "Construir um palácio - propôs Narizinho - cheio de quadros preciosos e estátuas, e um jardim de inverno, e estufas para flores raras - e tanta coisa vovó" (LOBATO, 1968, p. 211).

Dona Benta a repreende questionando o que fariam com o palácio, se já moravam numa "casinha gostosa" como aquela, não havia necessidade de ostentação; para a senhora já eram felizes ali, da forma como viviam. Desta forma, Dona Benta afirma:

O dinheiro foi feito para circular, não para apodrecer nas arcas; mas em vez de gasta-lo egoisticamente só conosco, como fazem os mais ricos, podemos gastá-lo de modo a beneficiar os milhares de pobrezinhos que nunca tiraram petróleo (LOBATO, 1968, p. 212).

\begin{tabular}{|l|l|l|l|l|l|}
\hline Interface da Educ. & Paranaíba & v. 1 & n. 1 & p. 32-52 & 2010 \\
\hline
\end{tabular}


O deslumbramento frente ao dinheiro logo se tornou para Narizinho algo sem importância após ouvir as intervenções de Dona Benta, por isso, ela irá propor a construção de boas escolas profissionais para os caboclos da região, médicos e "casas decentes e higiênicas", como relatamos no item anterior. Percebemos, portanto que o deslumbre se reverteu em responsabilidade social por parte da menina. As transformações da Vila do Tucano Amarelo foram inúmeras, uma delas foi a Escola Técnica de Narizinho que:

\footnotetext{
[...] tornou-se um padrão copiado pelo País inteiro. Os rapazes e as raparigas que lá se diplomavam em inúmeros ofícios, eram disputados a peso de ouro. "aqui se aprende de verdade" era o letreiro que havia na fachada do estabelecimento - e aprendia-se mesmo (LOBATO, 1968, p. 222).
}

Além dessa escola, a menina também sugeriu que "casas de abrigo" fossem criadas, assim os viajantes poderiam se acomodar à vontade e sem pagar nada, o que, na opinião dela era "a evolução dos antigos ranchos de tropeiros" (LOBATO, 1968, p. 223).

A responsabilidade social que Narizinho vem propor tem como objetivo o aumento da eficiência dos trabalhadores rurais, agora transformados em trabalhadores racionais que são "adaptados" na concepção fordista de produção. Narizinho representa, portanto, a ética lobatiana que pode ser observada através dos seus livros e artigos destinados ao público adulto, ética pautada na crítica à uma elite intelectual que assistia sem fazer nada para amenizar a miséria que a nossa população rural enfrentava. Seu desejo se concretiza no plano da utopia, onde conseguiu imaginar uma sociedade industrial, moderna e civilizada.

Deste modo, podemos notar, que no Brasil do futuro, construído pelas crianças, no Sítio do Picapau Amarelo, ocorre um processo de permanência do Brasil presente, real e tradicional em muitos aspectos. $\mathrm{O}$ que pode ser notado no que concerne às relações raciais neste universo. As crianças continuam a propagar uma inferioridade pertencente aos negros, devido a "ignorância" e a "falta de cultura" que atribuem à Tia Nastácia. O país do futuro, que Lobato acreditou construir não se desvencilhava do racismo presente.

Além do processo de permanência, também encontramos em muitos pontos, um processo de transformação da forma de organização econômica e financeira que o país estava vivenciando. É por meio dos projetos infantis descritos neste capítulo, que podemos perceber que Lobato era um fervoroso adepto de uma sociedade que se organizasse em torno de um capitalismo eficiente, onde patrões e empregados se "associassem" em prol da construção de um país que seus

\begin{tabular}{|l|c|c|c|c|c|}
\hline Interface da Educ. & Paranaíba & v. 1 & n. 1 & p. 32-52 & 2010 \\
\hline
\end{tabular}


habitantes refletissem e agissem sobre os seus principais problemas.

\section{Referências}

AZEVEDO, CAMARGOS \& SACCHETTA. Monteiro Lobato: furacão na Botocúndia. São Paulo: Senac, 1997.

BARREIRA, Luís Carlos. Anísio Teixeira e doutrina do nacional-desenvolvimentismo. In: MONARCHA, Carlos. (Org.) Anísio Teixeira: a obra de uma vida. Rio de Janeiro: DP\&A, 2001.

BICALHO, Maria Fernanda Baptista, O belo sexo: imprensa e identidade feminina no Rio de Janeiro em fim do século XIX e início do século XX. In: COSTA, Albertina de O. \& BRISCHINI (Org.) Rebeldia e submissão: estudos sobre a condição feminina. São Paulo: Fundação Carlos Chagas, 1989.

BOSI, Alfredo, As letras na Primeira República. In: FAUSTO, Bóris (Org.). História da civilização brasileira. São Paulo: Difel, 1977. V. III.

CAMPOS, André Luiz Vieira de. A república do picapau amarelo, uma leitura de Monteiro Lobato. São Paulo: Ed.Martins Fontes, 1986.

CANDIDO, Antonio. Literatura e sociedade: estudos de teoria e história literária, São Paulo: Companhia Editorial Nacional, 1967.

A Personagem do Romance. In: (Org.). A Personagem de Ficção. São Paulo: Perspectiva, 1995.

Itinerários Intelectuales: Vasconcelos, Lobato y sus proyectos para la nacion, Centro Coordinador y Difusor de Estudos Latinoamericanos, México, 2004.

LAJOLO, Marisa. Monteiro Lobato [A Modernidade do Contra]. São Paulo: Ed. Brasiliense, 1985.

LOBATO, Monteiro. Histórias de Tia Nastácia. São Paulo: Brasiliense, 1968.

. Mr. Slang e o Brasil. São Paulo: Brasiliense, 1959.

. O poço do Visconde. São Paulo: Brasiliense, 1960.

. Reinações de Narizinho. São Paulo: Brasiliense, 1969.

Serões de Dona Benta. São Paulo: Brasiliense, 1960.

MONTEIRO, Pedro Meira. Luzes ao campo, luzes à nação: o discurso ilustrado sobre a agricultura num período pré-independência e a idealização da nação civilizada. Trabalho de Conclusão de Curso - Universidade Estadual de Campinas, Campinas, ano 4, n. 5, 1994.

NAGLE, Jorge. A educação na primeira república. In: HOLANDA, Sérgio Buarque de (Org.).

\begin{tabular}{|l|l|l|l|l|l|}
\hline Interface da Educ. & Paranaíba & v. 1 & n. 1 & p. 32-52 & 2010 \\
\hline
\end{tabular}


História Geral da Civilização Brasileira: O Brasil Republicano. São Paulo: São Paulo: Difel, 1985. V. III.

Educação e sociedade na primeira República. São Paulo: Editora Pedagógica e Universitária Ltda, 1974.

NUNES, Cassiano. Monteiro Lobato e Anísio Teixeira: o sonho da educação no Brasil. In: MONARCHA, Carlos (Org.). Anísio Teixeira: a obra de uma vida. Rio de Janeiro: DP\&A, 2001.

ORTIZ, Renato. Cultura e identidade nacional. São Paulo: Brasiliense, 1985. 1995.

SCHWARZ, Roberto. Duas meninas. São Paulo: Companhia das Letras, 1997.

. As idéias fora do lugar. In: Ao vencedor as batatas: forma literária e processo social nos inícios do romance brasileiro. São Paulo: Duas cidades, 2000.

Que horas são?. São Paulo: Companhia das Letras, 1987. Ensaios.

SOUZA, Jessé. Modernização seletiva: uma reinterpretação do dilema brasileiro. Brasília: Editora UNB, 2000.

TEIXEIRA, Anísio. Educação no Brasil. Brasília: Companhia Editora Nacional, 1976.

ZILBERMAN, Regina. A literatura infantil na escola. São Paulo: FTD, 1988.

Interface da Educ.

Paranaíba

v. 1

n. 1

p. $32-52$

2010 